\author{
RENATA BADOWIEC \\ Uniwersytet Mikołaja Kopernika w Toruniu \\ r.badowiec@umk.pl
}

ORCID: 0000-0001-7912-1363

\title{
Relacje między prawem pracy a prawem karnym procesowym
}

\author{
Relations between labor law and criminal procedural law
}

Streszczenie. Na kwestie związane z prawami i obowiązkami pracowników i pracodawców mogą mieć wpływ także inne regulacje, które nie wynikają wprost z kodeksu pracy, czy innych aktów regulujących wyżej wskazaną materię. W obecnej rzeczywistości prawnej nie ma możliwości, aby poszczególne gałęzie prawa nie wykazywały między sobą spójności. Mimo więc obowiązywania odrębnych regulacji w stosunku do prawa pracy i postępowania karnego, dziedziny te pozostają ze sobą w pewnych relacjach, mimo że z żadnych przepisów kodeksu pracy ani kodeksu postępowania karnego zależności te wprost nie wynikają. Niniejszy artykuł ma na celu przedstawienie wpływu i wzajemnych relacji zachodzących między prawem pracy a prawem karnym procesowym na przykładzie udziału Państwowej Inspekcji Pracy w postępowaniu karnym, prawnego obowiązku zawiadomienia o popełnieniu przestępstwa oraz związania sądów pracy orzeczeniami sądów karnych.

Słowa kluczowe: prawo pracy; postępowanie karne; Państwowa Inspekcja Pracy; prawny obowiązek zawiadomienia o popełnieniu przestępstwa; związanie sądu pracy orzeczeniem sądu karnego.

Summary. Issues related to the rights and obligations of employees and employers may also be affected by other regulations that do not result directly from the Labor Code or other acts regulating the aforementioned matter. In the current legal reality, it is not possible for particular branches of law to not show coherence among themselves. Therefore, despite the application of separate regulations in relation to labor law and criminal proceedings, these areas remain in certain relations with each other, despite the fact that no provisions of the Labor Code or the Code of Criminal Procedure directly arise. This article aims to present the impact and mutual relations between labor law and criminal procedural law on the example of the participation of the National Labor Inspectorate in criminal proceedings, the legal obligation to notify about committing a crime and binding labor courts with criminal court rulings.

Keywords: labor law; criminal proceedings; National Labour Inspectorate; legal obligation to notify about committing a crime; binding the labor court with a criminal court ruling.

Data przesłania artykułu do Redakcji: 10.05.2020 r.

Data akceptacji artykułu przez Redakcję: 8.08.2020 r. 


\section{Wstęp}

Obecnie obowiązujący k.p. ${ }^{1}$ zgodnie z treścią art. 1 określa prawa i obowiązki pracowników i pracodawców. Z przepisu art. $9 \S 1$ k.p. wynika natomiast, że przez pojęcie ,„prawo pracy” należy rozumieć przepisy k.p. oraz przepisy innych ustaw i aktów wykonawczych, określające prawa i obowiązki pracowników i pracodawców, a także postanowienia układów zbiorowych pracy i innych opartych na ustawie porozumień zbiorowych regulaminów i statutów określających prawa i obowiązki stron stosunku pracy. Brzmienie tego przepisu wskazuje, że w jego treści chodzi o zdefiniowanie pojęcia prawa pracy, używanego na gruncie różnych przepisów k.p. Świadczy o tym posłużenie się przez ustawodawcę zwrotem „,ilekroć w Kodeksie pracy jest mowa o (...)”. Konsekwencją obowiązywania regulacji art. $9 \S 1$ k.p. jest to, że do gałęzi, jaką jest prawo pracy, zalicza się jedynie te akty prawne, które odnoszą się do wyżej wskazanych materii, tj. praw i obowiązków pracowników i pracodawców ${ }^{2}$.

Należy jednak zwrócić uwagę na fakt, że na kwestie związane $\mathrm{z}$ prawami i obowiązkami pracowników i pracodawców mogą mieć wpływ także inne regulacje, które bezpośrednio nie są związane z wyżej wskazaną materią. Niniejszy artykuł ma na celu przedstawienie takiego właśnie wpływu i wzajemnych relacji zachodzących między prawem pracy a prawem karnym procesowym na przykładzie udziału Państwowej Inspekcji Pracy w postępowaniu karnym, prawnego obowiązku zawiadomienia o popełnieniu przestępstwa oraz związania sądów pracy orzeczeniami sądów karnych. W wyniku tej analizy możliwe będzie wykazanie wpływu regulacji obowiązujących w k.p.k. ${ }^{3}$ na prawo pracy.

\section{Relacje między prawem pracy a prawem karnym}

Zanim poruszone zostaną zagadnienia dotyczące relacji między prawem pracy a prawem karnym procesowym, trzeba na początku zwrócić uwagę także na relacje, które zachodzą między prawem pracy a szeroko rozumianym prawem karnym, bowiem w jego ramach, obok prawa karnego procesowego, można wyróżnić prawo karne materialne oraz prawo karne wykonawcze. W kontekście związków między prawem pracy i prawem karnym materialnym nie można pominąć przepisów regulujących przestępstwa przeciwko prawom osób wykonujących pracę zarobkową. Prawo karne powinno oczywiście wkraczać jedynie w te sfery stosunków społecznych, dla których regulacje przewidziane w innych dziedzinach

\footnotetext{
${ }^{1}$ Ustawa z dnia 26 czerwca 1974 r. Kodeks pracy, Dz.U. z 1974 r. Nr 24, poz. 141 z późn zm.

2 J. Stelina, [w:] Kodeks pracy. Komentarz, A. Sobczyk (red.), Legalis.

${ }^{3}$ Ustawa z dnia 6 czerwca 1997 r. - Kodeks postępowania karnego, Dz.U. z 1997 r. Nr 89, poz. 555 z późn. zm.
} 
prawa są niewystarczające. Dlatego też pojawia się pytanie o zasadność i zakres stosowania instrumentów prawa karnego w stosunkach pracy. Należy jednak zauważyć, że pracownik jako słabsza strona stosunku pracy posiada szereg uprawnień gwarantowanych przez różne ustawy. Wśród najważniejszych uprawnień można wymienić prawo do: wynagrodzenia, wypoczynku, poszanowania i nienaruszalności godności, równego traktowania w zakresie warunków pracy i płacy, niedyskryminacji, wolności zrzeszania się, bezpiecznych i higienicznych warunków pracy. Pracodawcy, którzy naruszają prawa pracownicze, narażają się na odpowiedzialność przewidzianą w przepisach k.p., ale w przypadku najcięższych naruszeń mogą podlegać także odpowiedzialności karnej ${ }^{4}$.

Warto wskazać, że ewolucja powiązań między prawem pracy a prawem karnym wykształciła w literaturze sformułowanie „prawo karne pracy”, które oczywiście nie oznacza odrębnej gałęzi czy działu prawa, ale stanowi pojęcie podobne do funkcjonującej już nazwy „prawo karne gospodarcze”. Tak rozumiane „prawo karne pracy” obejmuje zarówno przepisy przewidujące odpowiedzialność za przestępstwa, takie jak wyżej wskazane przepisy k.k. regulujące przestępstwa przeciwko prawom osób wykonujących pracę zarobkową, jak i przepisy przewidujące odpowiedzialność za wykroczenia, które przede wszystkim znajdują się $\mathrm{w}$ przepisach k.p. Warto jednak wskazać, że przepisy dotyczące odpowiedzialności za przestępstwa oraz za wykroczenia znajdują swoje źródło również w innych ustawach ${ }^{6}$, np. ustawie o związkach zawodowych ${ }^{7}$ czy ustawie o rozwiązywaniu sporów zbiorowych ${ }^{8}$.

Jak zostało już wyżej wskazane, w ramach szeroko rozumianego prawa karnego wyróżnić można także prawo karne wykonawcze. Regulacje przyjęte w k.k.w. ${ }^{9}$ również stanowią przykład związków między prawem pracy a szeroko rozumianym prawem karnym. Warto wskazać chociażby na art. 121 k.k.w., zgodnie z którym skazanemu zapewnia się W miarę możliwości świadczenie pracy. Skazanego zatrudnia się: na podstawie skierowania do pracy, w ramach umowy o pracę, w ramach umowy zlecenia, w ramach umowy o pracę nakładczą albo na innej podstawie prawnej. Z punktu widzenia niniejszego opracowania najbardziej istotna jest oczywiście możliwość zatrudnienia skazanego na podstawie umowy o pracę. Należy zwrócić uwagę również na treść art. $121 \S 7$ k.k.w., ponieważ wynika z niego,

\footnotetext{
${ }^{4}$ J. Marciniak, Prawnokarna ochrona praw osób wykonujących pracę zarobkowa, Prokuratura i Prawo 2011, nr 2, s. 60-61.

${ }^{5}$ W. Radecki, Granice ingerencji prawa karnego w stosunki pracy, Prokuratura i Prawo 2005, nr 6, s. 18; J. Marciniak, Prawo karne pracy - wybrane zagadnienia, Radca Prawny 2010, nr 1, s. 8-13.

${ }^{6}$ W. Radecki, Granice ingerencji..., s. 18-19.

${ }^{7}$ Art. 35 ustawy z dnia 23 maja 1991 r. o związkach zawodowych, Dz. U. z 1991 r. Nr 55, poz. 234 z późn. zm.

8 Art. 26 ustawy z dnia 23 maja 1991 r. o rozwiązywaniu sporów zbiorowych, Dz.U. z 1991 r. $\mathrm{Nr} 55$, poz. 236 z późn. zm.

${ }^{9}$ Ustawa z dnia 6 czerwca 1997 r. - Kodeks karny wykonawczy, Dz.U. z 1997 r. Nr 90, poz. 557 z późn. zm.
} 
że w stosunku do skazanych pracujących, w zakresie nieuregulowanym przepisami k.k.w., stosuje się przepisy prawa pracy. Odzwierciedleniem tej regulacji jest jeden z wyroków Sądu Najwyższego, w którym wskazał, że skazany, który uległ wypadkowi przy wykonywaniu pracy w czasie odbywania kary pozbawienia wolności, ma prawo do świadczeń z tytułu tego wypadku na zasadach przewidzianych dla pracowników ${ }^{10}$. W przypadku zatrudnienia osób wykonujących karę pozbawienia wolności na podstawie skierowania do pracy zastosowania nie znajdują przepisy prawa pracy, jednak ustawodawca wskazał, że stosuje się te, które dotyczą czasu pracy oraz bezpieczeństwa i higieny pracy.

Ze względu na wagę czynów zabronionych, obok prawa karnego sensu stricto wyróżnić można również prawo wykroczeń. W tym kontekście warto wskazać na przepisy k.p., które w dziale XIII regulują odpowiedzialność za wykroczenia przeciw prawom pracownika. Należy w tym miejscu przywołać również art. 48 k.w. ${ }^{11}$, zgodnie z treścią którego przepisy części ogólnej k.w. stosuje się do wykroczeń przewidzianych w innych ustawach, jeżeli ustawy te nie zawierają przepisów odmiennych. Regulacja ta dotyczy więc wykroczeń przeciwko prawom pracownika ujętym w przepisach k.p. Oczywiście w sytuacji, w której pracodawca w rażący sposób będzie naruszał uprawnienia pracowników, będzie mógł wtedy ponieść odpowiedzialność karną, gdy jego zachowanie wypełni znamiona któregoś z czynów zabronionych uregulowanych w k.k.

\section{Relacje między prawem pracy a prawem karnym procesowym}

\subsection{Udzial Państwowej Inspekcji Pracy w charakterze pokrzywdzonego w postępowaniu karnym}

Ustawodawca będąc świadomym specyfiki przestępstw $z \quad$ Rozdziału XXVIII k.k. (przestępstwa przeciwko prawom osób wykonujących pracę zarobkową), a także chcąc realizować zasadę ochrony pracownika ze względu na jego szczególną pozycję, mniej uprzywilejowaną $\mathrm{W}$ stosunku do pracodawcy, zdecydował się w 2008 r. na znowelizowanie art. 49 k.p.k., wprowadzając do niego § 3a. Jest to próba zwiększenia poziomu wykrywalności przestępstw przeciwko prawom osób wykonujących pracę zarobkową, ponieważ organy Państwowej Inspekcji Pracy mogą także stanowić dodatkowe

\footnotetext{
${ }^{10}$ Wyrok Sądu Najwyższego z dnia 6 grudnia 2000 r., III CKN 48/00, Legalis nr 278433.

${ }^{11}$ Ustawa z dnia 20 maja 1971 r. - Kodeks wykroczeń, Dz.U. z 1971 r. Nr 12, poz. 114 z późn. zm.
} 
wsparcie merytoryczne dla oskarżycieli, działając jako dodatkowe podmioty w postępowaniu karnym, posiadające wiedzę specjalistyczną z zakresu prawa pracy ${ }^{12}$.

Zgodnie z treścią art. 49 § 3a k.p.k. w sprawach o przestępstwa przeciwko prawom osób wykonujących pracę zarobkową, o których mowa w art. 218-221 oraz w art. $225 \S 2$ k.k., organy Państwowej Inspekcji Pracy mogą wykonywać prawa pokrzywdzonego, jeżeli w zakresie swojego działania ujawniły przestępstwo lub wystąpiły o wszczęcie postępowania. Zgodnie z treścią art. 17 ustawy o Państwowej Inspekcji Pracy ${ }^{13}$ organami Państwowej Inspekcji Pracy są: Główny Inspektor Pracy, okręgowi inspektorzy pracy oraz inspektorzy pracy, którzy działają w ramach właściwości terytorialnej okręgowych inspektorów pracy. Działanie organów Państwowej Inspekcji Pracy będzie wyłączone w sytuacji, gdy przestępstwo zostało ujawnione przez inny organ, samego pokrzywdzonego lub też osobę trzecią albo gdy przestępstwo zostało ujawnione w trakcie czynności nienależących do zakresu działania organów Państwowej Inspekcji Pracy ${ }^{14}$.

Działalność Państwowej Inspekcji Pracy na podstawie art. 49 § 3a k.p.k. należy odróżnić od wykonywania uprawnień przysługujących jej na podstawie art. 49 § 4 k.p.k. (na podstawie tego przepisu $\mathrm{w}$ sprawach o przestępstwa, którymi wyrządzono szkodę w mieniu instytucji lub jednostki organizacyjnej, której odrębne przepisy przyznają zdolność prawną, jeżeli nie działa organ pokrzywdzonej instytucji lub jednostki organizacyjnej, prawa pokrzywdzonego mogą wykonywać organy kontroli państwowej, które w zakresie swojego działania ujawniły przestępstwo lub wystąpiły o wszczęcie postępowania). W pierwszym przypadku chodzi o działanie na rzecz pokrzywdzonego będącego osobą fizyczną wyłącznie w sprawach o przestępstwa przeciwko prawom osób wykonujących pracę zarobkową, natomiast $\mathrm{w}$ drugim przypadku mowa jest o wykonywaniu praw pokrzywdzonego w sprawach o przestępstwa, w wyniku których wyrządzono szkodę w mieniu nieposiadającej osobowości prawnej instytucji państwowej, samorządowej lub innej jednostki organizacyjnej, której odrębne przepisy przyznają zdolność prawną ${ }^{15}$.

Należy wskazać, że organom wykonującym prawa pokrzywdzonego przysługują zasadniczo te same prawa, które może realizować sam pokrzywdzony. Realizacja tych praw ma charakter pochodny. $\mathrm{W}$ art. 49 § 3a k.p.k. ustawodawca nie dokonał w tym zakresie

\footnotetext{
${ }^{12}$ P. Potocki, Rola Inspektora Pracy jako organu wykonujacego uprawnienia oskarżyciela, [w:] Uczestnicy postepowania karnego $w$ świetle nowelizacji procedury karnej po 1.7.2015 r. Komentarz praktyczny, P. Czarnecki, M. Czerwińska (red.), Legalis; J. Unterschütz, Karnoprawna ochrona praw osób wykonujacych prace zarobkowa, LEX/el.

${ }^{13}$ Ustawa z dnia 13 kwietnia 2007 r. o Państwowej Inspekcji Pracy, Dz.U. z 2007 r. Nr 89, poz. 589 z późn. zm.

${ }^{14}$ D. Kużelewski, System prawa karnego procesowego. T. VI. Strony i inni uczestnicy postępowania karnego, C. Kulesza (red.), Warszawa 2017, s. 363.

${ }^{15}$ Ibidem.
} 
żadnego ograniczenia. Organy Państwowej Inspekcji Pracy mogą tym samym wykonywać tylko te prawa pokrzywdzonego, które $\mathrm{w}$ danej sytuacji procesowej przysługują pokrzywdzonemu. Nie mogą one bowiem wykonywać uprawnień w takich sytuacjach, w których sam pokrzywdzony nie może ich realizować ${ }^{16}$. Istnieje jednak sytuacja, w której ustawodawca inaczej kreuje sytuację organów Państwowej Inspekcji Pracy. Chodzi o regulację art. 325e § 1a k.p.k., zgodnie z którą w przypadku gdy zawiadomienie o przestępstwie zostało złożone przez inspektora pracy lub Najwyższą Izbę Kontroli, uzasadnienie postanowienia o odmowie wszczęcia dochodzenia oraz umorzeniu dochodzenia sporządza się na ich wniosek. W takiej sytuacji zażalenie wnosi się w terminie 7 dni od daty doręczenia postanowienia z uzasadnieniem. Sytuacja wygląda inaczej w stosunku do stron postępowania, ponieważ podmioty te mogą jedynie liczyć na podanie ustnie najważniejszych powodów rozstrzygnięcia, jeżeli strona złoży wniosek. Podstawą wprowadzenia przez ustawodawcę takiego rozwiązania było przekonanie, że na skuteczność działania Państwowej Inspekcji Pracy wpływa fakt, że wydawane w postępowaniu karnym postanowienie o odmowie wszczęcia dochodzenia czy też o jego umorzeniu, choć jest zaskarżalne, nie wymaga sporządzenia przez prokuratora uzasadnienia. W związku z tym wniesienie zażalenia jest trudne, bowiem nie wiadomo, jakie konkretnie przesłanki zdecydowały o podjęciu określonego rodzaju decyzji przez prowadzącego postępowanie prokuratora. W związku z tym ustawodawca uznał, że wprowadzenie w sprawach, w których inspektor pracy skierował zawiadomienie o podejrzeniu popełnienia przestępstwa, obowiązku uzasadnienia, na wniosek inspektora pracy, nie tylko przyczyni się do zwiększenia efektywności działania Państwowej Inspekcji Pracy, ale pozwoli również na skuteczne ściganie przestępstw, W szczególności przeciwko prawom osób wykonujących pracę zarobkową ${ }^{17}$.

Organy Państwowej Inspekcji Pracy zaliczane są również do państwowych organów kontroli. Jednak w wyniku dodania $\S 3 \mathrm{a}$ w art. 49 k.p.k. został im wyznaczony szczególny zakres możliwości działania. W związku z tym inaczej niż organy kontroli państwowej, o których jest mowa w art. 49 § 2 k.p.k., organy Państwowej Inspekcji Pracy mogą swobodnie występować obok pokrzywdzonego zarówno w postępowaniu przygotowawczym, jak i na rozprawie głównej. Możliwe są więc trzy konfiguracje wzajemnych stosunków pomiędzy

\footnotetext{
${ }^{16}$ Postanowienie Sądu Najwyższego z dnia 26 marca 2009 r., I KZP 2/09, OSNKW 2009, Nr 5, poz. 37 , s. 48.

${ }^{17}$ Druk nr 3870 o zmianie ustawy o Państwowej Inspekcji Pracy oraz o zmianie niektórych innych ustaw, s. 16, http://orka.sejm.gov.pl/Druki6ka.nsf/0/FB1D222F9C374C78C1257840002A62CA/\$file/3870.pdf, [dostęp: 4.05.2020 r.].
} 
tymi podmiotami ${ }^{18}$. Po pierwsze, pokrzywdzony może samodzielnie wykonywać swoje uprawnienia. W takiej sytuacji już na etapie wszczęcia postępowania karnego odpowiedni organ Państwowej Inspekcji Pracy będzie musiał zdecydować o rezygnacji z uczestnictwa $\mathrm{w}$ tym postępowaniu w związku z tym, że jego ingerencja nie będzie potrzebna dla uzyskania stanu zgodnego z prawem. Druga możliwość obejmuje sytuacje, w których pokrzywdzony zachowa bierną postawę w postępowaniu karnym. W takich wypadkach organ Państwowej Inspekcji Pracy może samodzielnie wykonywać uprawnienia osoby, w której imieniu będzie działał w postępowaniu karnym. Takie sytuacje najczęściej mają miejsce, gdy organ Państwowej Inspekcji Pracy w ramach swoich ustawowych obowiązków polegających m.in. na nadzorze i kontroli przestrzegania przepisów prawa pracy, w szczególności zasad bezpieczeństwa i higieny pracy oraz przepisów dotyczących stosunku pracy, wynagrodzenia za pracę i innych świadczeń, dostrzeże wystąpienie znamion czynu zabronionego i zwróci się do odpowiedniego organu procesowego $\mathrm{z}$ zawiadomieniem o możliwości popełnienia przestępstwa, a następnie postanowi wykonywać uprawnienia pokrzywdzonego ${ }^{19}$. Ostatnim przykładem konfiguracji wzajemnych stosunków między pokrzywdzonym a organem Państwowej Inspekcji Pracy jest sytuacja, w której oba te podmioty występują wspólnie w postępowaniu karnym. Mają one wówczas taki sam zakres możliwości, a działanie jednego z nich nie wyklucza możliwości podjęcia czynności przez drugiego ${ }^{20}$.

Dzięki możliwości korzystania przez organy Państwowej Inspekcji Pracy z uprawnień procesowych pokrzywdzonego zostały one wyposażone $\mathrm{w}$ istotne instrumenty walki procesowej, o ile oczywiście zdecydują się uczestniczyć aktywnie w postępowaniu karnym. Dopuszczenie jednak Państwowej Inspekcji Pracy do występowania w procesie karnym w charakterze pokrzywdzonego może okazać się korzystne z punktu widzenia ochrony praw pracowników, zwłaszcza ze względu na znaczną wiedzę praktyczną w zakresie prawa pracy, którą dysponują często te podmioty $\mathrm{w}$ porównaniu $\mathrm{z}$ prowadzącymi postępowania karne $\operatorname{organami}^{21}$. Fakt, że dobro chronione przepisami rozdziału XXVIII k.k. jest dobrem indywidualnym, ale o szczególnym znaczeniu społecznym, powoduje, że organy Państwowej Inspekcji Pracy mogą być uznane za rzeczników interesów społecznych, ponieważ stosunki

\footnotetext{
${ }^{18}$ K. Woźniewski, Państwowa Inspekcja Pracy jako podmiot wykonujący prawa pokrzywdzonego w rozumieniu art. 49 § 3 a k.p.k. po nowelizacji, Gdańskie Studia Prawnicze 2008, t. XIX, s. 377.

${ }^{19}$ Ibidem, s. 377-390.

${ }^{20}$ P. Potocki, Rola Inspektora Pracy, LEX/el.

${ }^{21}$ J. Unterschütz, Karnoprawna ochrona praw osób wykonujacych pracę zarobkowa, LEX/el.
} 
społeczne związane z zatrudnieniem w procesie pracy są stosunkami, które wywierają wpływ nie tylko na życie pojedynczego człowieka, ale również całego społeczeństwa ${ }^{22}$.

\subsection{Skutki niewypełnienia prawnego obowiązku zawiadomienia o popełnieniu przestępstwa $z$ art. $304 \S 2$ k.p.k.}

Następnym odzwierciedleniem istniejących związków między prawem pracy a prawem karnym procesowym jest przepis art. $304 \S 2$ k.p.k., który reguluje prawny obowiązek złożenia zawiadomienia o popełnieniu przestępstwa ściganego z urzędu. Obowiązek ten dotyczy instytucji państwowych i samorządowych, które zobowiązane są do złożenia zawiadomienia o przestępstwie ściganym z urzędu, o którego popełnieniu dowiedziały się W związku ze swoją działalnością. Z punktu widzenia prawa pracy istotne będą konsekwencje niedopełnienia wyżej wskazanego obowiązku.

Obowiązek zawiadomienia o przestępstwie, przewidziany w art. 304 § 2 k.p.k., spoczywa na osobach pełniących funkcje kierownicze w instytucjach państwowych i samorządowych lub też osobach upoważnionych do reprezentowania instytucji. Obowiązkiem pracownika jest jedynie zawiadomić osoby sprawujące funkcje kierownicze ${ }^{23}$. Niewykonanie nakazu przewidzianego w treści art. 304 § 2 k.p.k. może stanowić przestępstwo określone w art. 231 k.k. w sytuacji, w której gdy funkcjonariusz publiczny zobowiązany na podstawie wyżej wskazanej regulacji do zgłoszenia, nie zawiadomił o przestępstwie ściganym z urzędu, pomimo świadomości tego, że je popełniono, a także gdy sam miał świadomość tego, że przekracza swoje uprawnienia lub nie dopełnia obowiązków i w ten sposób działa na szkodę interesu publicznego lub prywatnego ${ }^{24}$. Powstanie obowiązku zawiadomienia o popełnieniu przestępstwa uzależnione jest od dwóch przesłanek. Pierwsza dotyczy istnienia okoliczności wskazujących na popełnienie przestępstwa ściganego z urzędu, druga natomiast wymaga ,dowiedzenia się” przez instytucje wymienione w art. $304 \S 2$ k.p.k. o popełnieniu tego przestępstwa. Owo „dowiedzenie się” powinno nastąpić w związku z prowadzoną przez nie działalnością, a ponadto osoby działające w ramach instytucji państwowej lub samorządowej muszą mieć świadomość, że rzeczywiście zostało popełnione przestępstwo. Aby można było przypisać popełnienie przestępstwa określonego

\footnotetext{
${ }^{22}$ K. Woźniewski, Państwowa Inspekcja Pracy..., s. 377-389.

23 B. Szyprowski, Uzasadnione podejrzenie popetnienia przestęstwa jako faktyczna przesłanka wszczęcia postępowania przygotowawczego, Prokuratura i Prawo 2006, nr 3, s. 137.

${ }^{24}$ Wyrok Sądu Najwyższego z dnia 12 lutego 2008 r., WA 1/08, Legalis nr 95762.
} 
w art. $231 \S 1$ lub 2 k.k., konieczne jest też ustalenie strony podmiotowej w odniesieniu do całości zachowania sprawcy opisanego w powołanym przepisie ${ }^{25}$.

W kontekście prawnego obowiązku zawiadomienia o popełnieniu przestępstwa nie sposób nie wskazać na konsekwencje w postaci możliwości poniesienia odpowiedzialności dyscyplinarnej przez pracowników danej instytucji. W sytuacji, w której pracownik nie zawiadomił osób pełniących funkcje kierownicze w określonej instytucji o przestępstwie uregulowanym w art. $304 \S 2$ k.p.k., może narazić się na pociągnięcie do odpowiedzialności dyscyplinarnej. Trzeba wziąć pod uwagę treść art. 100 k.p., zgodnie z treścią którego pracownik jest obowiązany wykonywać pracę sumiennie i starannie, a także stosować się do poleceń przełożonych, które dotyczą pracy, jeżeli nie są one sprzeczne z przepisami prawa lub umową o pracę. Uzasadnioną przyczyną rozwiązania $\mathrm{z}$ pracownikiem umowy $\mathrm{i}$ to $\mathrm{w}$ trybie art. $52 \S 1$ pkt 1 k.p. może być zawinione działanie pracownika powodujące samo zagrożenie interesów pracodawcy ${ }^{26}$, a takim zachowaniem może być właśnie niezawiadomienie o przestępstwie ściganym z urzędu określone w art. 304 § 2 k.p.k. Dobro zakładu pracy obejmuje jego istnienie, rozwój oraz sprawne funkcjonowanie. Dlatego też jednym z podstawowych obowiązków pracowników uczyniono obowiązek dbałości o nie. Obowiązek ten został wprost wyrażony w art. $100 \S 2$ pkt 4 k.p. i obejmuje powinność dbania o mienie zakładu pracy oraz jego wartości niematerialne. Można przez to rozumieć zakaz szkodzenia przez pracownika pracodawcy i jednocześnie nakaz pozytywnego działania w interesie pracodawcy stosownie do potrzeby i możliwości, także ponad zwykły obowiązek. W ramach obowiązku dbałości o dobro zakładu pracy pracownik jest obowiązany podejmować w interesie zakładu pracy określone działania nawet wykraczające niekiedy poza treść umowy o pracę, zarówno na podstawie polecenia pracodawcy, jak i z własnej inicjatywy (bezwyraźnego polecenia). Dobro zakładu obejmuje bowiem sprawne funkcjonowanie zakładu pracy, a sprzeczne są z nim wszelkiego rodzaju awarie czy przestoje ${ }^{27}$. Należy wobec powyższego przyjąć, że w sytuacji, gdy w danej instytucji o popełnieniu przestępstwa ściganego z urzędu dowiedział się pracownik lub kilku pracowników, ich obowiązkiem jest zawiadomić o tym fakcie osoby sprawujące funkcje kierownicze. W przypadku braku działania osób uprawnionych do reprezentacji instytucji nie można czynić pracownikom zarzutu z tytułu braku osobistego zawiadomienia o przestępstwie. Natomiast w przypadku, gdy pracownik dowiedział się o popełnieniu przestępstwa, lecz nie zawiadomił o tym fakcie

\footnotetext{
${ }^{25}$ Ibidem

${ }^{26}$ Wyrok Sądu Najwyższego z dnia 27 marca 2019 r., II PK 321/17, Legalis nr 1894271.

${ }^{27}$ R. Salik, Obowiazek dbatości o dobro zaktadu pracy i skutki jego naruszenia, Monitor Prawa Pracy 2007, $\mathrm{nr} 12$, Legalis.
} 
kierownictwa instytucji, może ponieść odpowiedzialność dyscyplinarną, bowiem na nim spoczywa, zgodnie z art. $304 \S 1$ k.p.k., jedynie społeczny obowiązek zawiadomienia o przestępstwie ${ }^{28}$, ale $\mathrm{w}$ związku $\mathrm{z}$ faktem, iż niewypełnienie obowiązku zawiadomienia o popełnieniu przestępstwa osób sprawujących funkcje kierownicze w danej instytucji może być traktowane jako brak dbałości o dobro zakładu, stanowić to może podstawę do poniesienia właśnie odpowiedzialności dyscyplinarnej.

\subsection{Związanie sądu pracy orzeczeniem sądu karnego}

Ostatnim przykładem relacji między prawem pracy a prawem karnym procesowym, który zostanie poddany analizie na potrzeby niniejszego opracowania, jest związanie sądu cywilnego (sądu pracy) orzeczeniem sądu karnego. Oczywiście może wystąpić również sytuacja odwrotna, kiedy to sąd karny związany będzie orzeczeniem sądu cywilnego, jednak przypadki te z pewnością będą rzadsze, ponieważ sądy w postępowaniu karnym zasadniczo rozstrzygają samodzielnie zagadnienia faktyczne $\mathrm{i}$ prawne (wynika to $\mathrm{z}$ zasady samodzielności jurysdykcyjnej sądu karnego uregulowanej w art. $8 \S 1$ k.p.k.), a wiążące są jedynie prawomocne rozstrzygnięcia sądu kształtujące prawo lub stosunek prawny. Natomiast W postępowaniu cywilnym, zgodnie $\mathrm{z}$ treścią art. 11 k.p.c. ${ }^{29}$, „ustalenia wydanego w postępowaniu karnym prawomocnego wyroku skazującego co do popełnienia przestępstwa wiążą sąd w postępowaniu cywilnym”. Przepis ten ma charakter zasady procesowej, a nie jedynie normy dowodowej, wyraża bowiem zasadę ustępstwa procesu cywilnego na rzecz procesu karnego ${ }^{30}$. Wykładnia tego przepisu powinna być ścisła, nigdy rozszerzająca, bowiem regulacja art. 11 k.p.c. stanowi wyłom m.in. od zasady bezpośredniości ${ }^{31}$.

W przepisie art. 11 k.p.c. ustawodawca posłużył się pojęciem wyroku. Sąd w postępowaniu cywilnym związany jest więc ustaleniami, które zawarte zostały w wyroku. Należy jednak zwrócić uwagę na fakt, iż w przepisach dotyczących wyrokowania w k.p.k. uregulowane zostały kwestie dotyczące zarówno sentencji wyroku, jak i jego uzasadnienia. W związku z tym należy ustalić, czy sąd w postępowaniu cywilnym będzie związany jedynie sentencją wyroku w sprawie karnej czy także ustaleniami, które zostały zawarte w jego

\footnotetext{
${ }^{28}$ B. Szyprowski, Uzasadnione podejrzenie..., s. 138.

${ }^{29}$ Ustawa z dnia 17 listopada 1964 r. - Kodeks postępowania cywilnego, Dz.U. z 1964 r. Nr 43, poz. 296 z późn. $\mathrm{zm}$.

${ }^{30}$ F. Rosengarten, Prejudycjalność wyroku karnego w postępowaniu cywilnym, Nowe Prawo 1971, nr 12, s. 1793.

${ }^{31}$ A. Zieliński, [w:] Kodeks postępowania cywilnego. Komentarz, A. Zieliński, K. Flaga-Gieruszyńska (red.), Warszawa 2017, s. 51.
} 
uzasadnieniu $^{32}$. W myśl art. 11 k.p.c. istota związania polega jedynie na wyłączeniu dokonywania $\mathrm{w}$ postępowaniu cywilnym ustaleń innych niż te, których dokonał sąd W sentencji wyroku skazującego. Nie są wiążące natomiast ustalenia zawarte w uzasadnieniu wyroku skazującego $^{33}$. Związanie sądu w postępowaniu cywilnym będzie dotyczyło znamion przestępstwa oraz okoliczności jego popełnienia, dotyczących miejsca, czasu i poczytalności sprawcy, które zostały ustalone w sentencji tego właśnie wyroku. Nie będą wiążące dla sądu $\mathrm{w}$ postępowaniu cywilnym ustalenia, które zostały zawarte $\mathrm{w}$ uzasadnieniu prawomocnego wyroku skazującego, chyba że będzie chodziło o ustalenia stanowiące konieczną przesłankę do stwierdzenia przestępstwa określonego w sentencji wyroku ${ }^{34}$.

Od zasady związania sądu w postępowaniu cywilnym prawomocnym wyrokiem skazującym wydanym w postępowaniu karnym istnieje jednak wyjątek. Należy wskazać tu przepis art. 11 zd. 2 k.p.c., zgodnie z którym „osoba, która nie była oskarżona, może powoływać się w postępowaniu cywilnym na wszelkie okoliczności wyłączające lub ograniczające jej odpowiedzialność cywilną". Sam Sąd Najwyższy stoi na stanowisku, iż regulacja ta jest jedynie wyrazem tego, że osoba, która ponosi odpowiedzialność za cudze czyny może bronić się wszystkimi zarzutami przysługującymi jej z mocy przepisów prawa cywilnego, bez podważania jednak ustaleń co do popełnienia przestępstwa zawartych w prawomocnym wyroku skazującym. Ponadto art. 11 zd. 2 k.p.c. nie uchyla samej zasady związania sądu w postępowaniu cywilnym prawomocnym wyrokiem skazującym wydanym w postępowaniu karnym, ale daje wyraz temu, że zasada związania nie przesądza jeszcze o istnieniu odpowiedzialności cywilnej osoby, która nie była oskarżona ${ }^{35}$.

Warto także zwrócić uwagę na sytuację, w której oba postępowania toczyć się będą w jednym czasie. $Z$ punktu widzenia prawa pracy (postępowania cywilnego) sąd cywilny będzie miał możliwość z urzędu zawiesić toczące się postępowanie, jeżeli oceni, że ustalenie czynu stanowiącego podstawę żądania w postępowaniu karnym wpłynie na rozstrzygnięcie sprawy cywilnej ${ }^{36}$. Sąd w postępowaniu cywilnym postąpi tak w przypadku, kiedy oba postępowania będą toczyły się równocześnie lub gdy postępowanie karne nie zostanie jeszcze wszczęte $^{37}$. W takiej właśnie sytuacji zastosowanie znajdzie przepis art. $177 \S 1$ pkt 4 k.p.c., który stanowi, że ,sąd w postępowaniu cywilnym może zawiesić postępowanie z urzędu, jeśli

\footnotetext{
${ }^{32}$ K. Piasecki, Wplyw postępowania i wyroku karnego na postepowanie $i$ wyrok cywilny, Warszawa 1970, s. 117.

${ }^{33}$ Wyrok Sądu Najwyższego z dnia 2 lutego 2012 r., II CSK 330/11, Legalis nr 473589.

${ }^{34}$ Wyrok Sądu Najwyższego z dnia 4 kwietnia 2014 r., II CSK 405/13, Legalis nr 998538; podobnie wyrok Sądu Apelacyjnego w Szczecinie z dnia 29 maja 2013 r., I ACa 343/08, Legalis nr 1241418.

${ }^{35}$ A. Zieliński, [w:] Kodeks postępowania cywilnego..., s. 56.

${ }^{36}$ J. Cagara, Związanie sądu cywilnego wyrokiem karnym, Nowe Prawo 1981, nr 3, s. 39.

${ }^{37}$ Ibidem, s. 40.
} 
ujawni się czyn, którego ustalenie w drodze karnej lub dyscyplinarnej mogłoby wywrzeć wpływ na rozstrzygnięcie sprawy cywilnej”. Ujęta w ten sposób norma wskazuje na dwie możliwe sytuacje: jedną, w której brak będzie podstaw do zawieszenia postępowania przez sąd oraz drugą, gdy zawieszenie takie okaże się być obowiązkiem sądu w postępowaniu cywilnym $^{38}$. Fakultatywność nie oznacza jednak dowolności w podjęciu przez sąd decyzji o zawieszeniu postępowania. Będzie ona bowiem zależała nie tylko od istnienia określonych przesłanek przewidzianych w art. $177 \S 1$ pkt 4 k.p.c., ale również od względów celowości ${ }^{39}$. Sąd będzie więc musiał przeanalizować stosunek danej sprawy toczącej się w postępowaniu cywilnym do charakteru wyników toczącego się (lub mogącego się toczyć) innego postępowania $^{40}$. Ustawodawca posługując się zwrotami „może zawiesić” i „mogłoby wywrzeć wpływ” zakłada jednocześnie taki przypadek, w którym ustalenie czynu w drodze karnej ostatecznie nie będzie miało wpływu na rozstrzygnięcie sprawy cywilnej ${ }^{41}$.

\section{Podsumowanie}

Jak widać z wyżej przeprowadzonych rozważań, prawo pracy ma wiele wspólnych punktów z szeroko rozumianym prawem karnym, a także prawem karnym procesowym. Mimo że kwestie związane $\mathrm{z}$ prawem pracy częściej związane są $\mathrm{z}$ prawem cywilnym (w samym art. 300 k.p. zostało wskazane, że w sprawach nieunormowanych przepisami prawa pracy stosuje się odpowiednio przepisy Kodeksu cywilnego, jeżeli nie są one sprzeczne z zasadami prawa). W przypadku relacji z prawem karnym ustawodawca nie zdecydował się na wprowadzenie podobnej regulacji w k.p. Oczywiście przyczyną tego jest fakt, że prawo pracy i prawo karne regulują zupełnie różne zagadnienia i sfery życia społecznego. Nie pozostają jednak w całkowitym oderwaniu od siebie. Jak już bowiem zostało wcześniej wskazane, nawet $\mathrm{w}$ regulacjach k.p. ustawodawca przewidział cały dział poświęcony wykroczeniom przeciwko prawom pracownika. Ponadto rażące zachowania pracodawcy mogą skutkować jego odpowiedzialnością na gruncie prawa karnego. Warto również pamiętać, że mimo obowiązywania odrębnych regulacji w stosunku do prawa pracy i postępowania karnego, dziedziny te pozostają ze sobą w pewnych relacjach, mimo że z żadnych przepisów k.p. ani k.p.k. te zależności wprost nie wynikają. W obecnej rzeczywistości prawnej nie ma jednak możliwości, aby poszczególne gałęzie prawa nie wykazywały między sobą spójności. W tym właśnie celu ustawodawca wprowadził przepisy,

\footnotetext{
${ }^{38}$ K. Piasecki, Wptyw postępowania i wyroku karnego..., s. 177.

${ }^{39}$ A. Jakubecki, Prejudycjalność w postępowaniu cywilnym, Nowe Prawo 1982, nr 7-8, s. 98.

${ }^{40}$ L. Ostrowski, O kwestiach prejudycjalnych $w$ procesie cywilnym, Palestra 1965, nr 11, s. 5.

${ }^{41}$ Ibidem, s. 178.
} 
które umożliwiają przenikanie się m.in. prawa pracy i prawa karnego, w tym prawa karnego procesowego, chociaż sfery te zasadniczo regulują zupełnie różne materie.

\section{Bibliografia:}

\section{Literatura}

Cagara J., Zwiazanie sądu cywilnego wyrokiem karnym, „Nowe Prawo” 1981, nr 3

Czarnecki P., Czerwińska M. (red.), Uczestnicy postępowania karnego $w$ świetle nowelizacji procedury karnej po 1.7.2015 r. Komentarz praktyczny, Legalis

Jakubecki A., Prejudycjalność w postępowaniu cywilnym, „Nowe Prawo” 1982, nr 7-8

Kulesza C. (red.), System prawa karnego procesowego. T. VI. Strony i inni uczestnicy posteppowania karnego, Warszawa 2017

Marciniak J., Prawnokarna ochrona praw osób wykonujacych pracę zarobkowa, „Prokuratura i Prawo" 2011, nr 2

Ostrowski L., O kwestiach prejudycjalnych w procesie cywilnym, „Palestra” 1965, nr 11

Piasecki K., Wpływ postępowania $i$ wyroku karnego na postępowanie $i$ wyrok cywilny, Warszawa 1970

Radecki W., Granice ingerencji prawa karnego w stosunki pracy, „Prokuratura i Prawo” 2005, nr 6 Rosengarten F., Prejudycjalność wyroku karnego w postępowaniu cywilnym, „Nowe Prawo” 1971, nr 12

Salik R., Obowiazek dbałości o dobro zakładu pracy i skutki jego naruszenia, „Monitor Prawa Pracy” 2007, nr 12

Sobczyk A. (red.), Kodeks pracy. Komentarz, Legalis

Szyprowski B., Uzasadnione podejrzenie popetnienia przestepstwa jako faktyczna przestanka wszczęcia postępowania przygotowawczego, „Prokuratura i Prawo” 2006, nr 3

Unterschütz J., Karnoprawna ochrona praw osób wykonujących pracę zarobkową, LEX/el.

Woźniewski K., Państwowa Inspekcja Pracy jako podmiot wykonujący prawa pokrzywdzonego w rozumieniu art. 49 \& 3 a k.p.k. po nowelizacji, „Gdańskie Studia Prawnicze” 2008, t. XIX

Zieliński A., Flaga-Gieruszyńska K. (red.), Kodeks postępowania cywilnego. Komentarz, Warszawa 2017

\section{Orzecznictwo}

Postanowienie Sądu Najwyższego z dnia 26 marca 2009 r., I KZP 2/09, OSNKW 2009, Nr 5, poz. 37

Wyrok Sądu Apelacyjnego w Szczecinie z dnia 29 maja 2013 r., I ACa 343/08, Legalis nr 1241418

Wyrok Sądu Najwyższego z dnia 6 grudnia 2000 r., III CKN 48/00, Legalis nr 278433

Wyrok Sądu Najwyższego z dnia 12 lutego 2008 r., WA 1/08, Legalis nr 95762

Wyrok Sądu Najwyższego z dnia 2 lutego 2012 r., II CSK 330/11, Legalis nr 473589

Wyrok Sądu Najwyższego z dnia 4 kwietnia 2014 r., I CSK 405/13, Legalis nr 998538

Wyrok Sądu Najwyższego z dnia 27 marca 2019 r., II PK 321/17, Legalis nr 1894271 